\title{
ANALYSIS OF LOAN DEFAULT AND REPAYMENT PERFORMANCE AMONG FARMERS IN AKWA IBOM STATE INTEGRATED FARMERS' SCHEME
}

\author{
Ekaette Akpan Etukumoh* \\ Department of Agricultural Economics and Extension, University of Uyo, \\ Akwa Ibom State, Nigeria \\ Aniekan Jim Akpaeti \\ Department of Agricultural Economics and Extension, Akwa Ibom State University, \\ Akwa Ibom State, Nigeria \\ *E-mail: ekaetukumoh@yahoo.com
}

\begin{abstract}
The study examined Agricultural Loan Default and repayment performance among Farmers in Nigeria: The case of the Akwa Ibom State Integrated Farmers' Scheme (IFS). Simple random sampling technique was used to select a total of 100 loan beneficiaries for the study30 IFS loan beneficiaries from the first batch and 70 beneficiaries from the second batch respectively. Tobit model was used to determine and analyze the explanatory variables influencing default rates of the IFS loan beneficiaries were found to be $9.4 \%$ and $99.91 \%$ respectively. Analysis of the data using Tobit model revealed that 8 explanatory variables, namely marital status, household size, off-farm income, total farm cost, enterprise profitability, debt-asset ratio, ratio of amount request ed/ given and number of visits of supervisors were significant factors influencing loan repayment among the beneficiaries. It is therefore recommended that Government should organize regular training programmes for IFS Supervisors to enhance effective supervision and appraisal of the agricultural projects. This will check the incessant waste of fund that disrupts prompt repayment of such loans and more vehicles should be provided by Government to enhance effective monitoring of the progress of participants' projects, assist when necessary and offer advice.
\end{abstract}

\section{KEY WORDS}

Loan default, repayment performance, beneficiaries, Integrated Farmers' Scheme.

One of the most important resource input promoting agricultural development is agricultural finance (Okam, 1994). This is in line with the fact that agricultural financing to the national economy cannot be overemphasized in view of its relevance in stemming hunger and assuring food security, reducing unemployment, solving balance of payment problem and increasing GDP (Inyang-Akpan, 2005). According to Derosa (1995), the growth of any economy apparently hinges on capital accumulation. The low level of capital formation has been one of the most inhibiting factors affecting effective agricultural production in Nigeria. Incidentally the level of capital formation is determined principally by the level of financial commitment to the farming business. Yoichiro and Hari (1996) noted that capital is a key constraint in the process of agricultural development in the rural and urban areas of most developing countries. This is because most farmers in the developing countries are smallholder farmers with low income levels resulting to low savings and investment (Lipsey, 1981). According to Edache (2006), food production in Nigeria is mostly carried out by small scale farmers and these set of farmers are known to be the backbone of the agricultural economy. However, these small scale farmers' productivity and production are hindered by the lack of funds for the purchase of the right type of fertilizer and access to credit to finance the farm business (Ladipo, 1986).

According to Ajekigbe (2006), credit constitute the power or key to unlock latent, abilities, visions, opportunities which in turn act as the mover of economic development. These crucial roles are what agricultural credit is expected to play in agricultural development (Duong and Izumida, 2002). But the inadequacy and dearth of credit for financing agriculture is one of the greatest problems facing agricultural development in most developing countries 
like Nigeria (Oyewole and Oloko, 2002) while Akubuilo (2002) added that inadequacy of loans and credit services is among the constraints against effective farming among rural farmers. It is in the realization of the fact that credit is a critical factor in agricultural development that the channeling of institutional finance to agriculture has increasingly become an important policy instrument for increasing agricultural output particularly of the rural poor. Unfortunately, in spite of the rapidly expanded agricultural loans in these countries, results of convectional agricultural credit programmes have seldom measured up to expectation. This is because of a number of reasons, which include the fact that not much progress has been made in reaching the small farmers and when the loan is available, poor loan management has contributed seriously to poor agricultural performance. Ajekigbe (2006) observed that despite governments' efforts at improving agricultural potentials, agricultural finance still faces challenges, some of which are inability of customers to satisfy credit standard, high default and attrition rate, lack of requisite skills and manpower deficiency, weak flow of information between farmers and lenders on opportunities available and inadequate record keeping.

In Akwa Ibom State and Nigeria as a whole, farmers source their credit from both institutional and non-institutional sources. The institutional sources include banks of any type, state owned agricultural credit institutions and cooperative credit unions while the noninstitutional sources include: licensed money lenders, Osusu clubs and association, members of the family, relatives, friends etc (Udoh, 2008). It is clear that most agricultural credit in the rural setting is supplied by the non-institutional source (Osuntogun, 1983; Udoh, 2008). This is because of low productivity, low income and the resulting inability of peasant farmers to accumulate capital. However, this study focuses on the institutional source, principally a state-owned agricultural credit institution namely, the Akwa lbom State Integrated Farmers' Scheme (IFS). The Integrated Farmers' Scheme (IFS) was established in 1997 under the Akwa Ibom State Ministry of Agriculture and managed as a project under the State micro-credits scheme. The Bill establishing the Scheme was signed into law in 2003. The Scheme was borne out of the desire or effort to exploit the vast untapped agricultural potentials of the state with the following objectives: training and empowerment of young school leavers to pursue a career in various agro-enterprises; strengthening the farm work-force by injecting the energetic youths to take up farming and replace the aging parents through the use of improved technology; reducing unemployment thereby curbing youth restiveness with attendance vices; promoting and dignifying farming as a viable business venture thus stimulating the growth of agriculture; providing self-employment to graduates of various levels of education and concomitant increase employers of these new cadre of entrepreneurs - decongesting the labour market; increasing food production and income levels in the state.

Empirically, high rate of loan delinquency is widely reported in literature especially among small holder farmers in developing economies. In Nigeria, several researchers (Obi, 1980 and Okorie, 1985) reported default rates ranging from $9.7 \%$ to $67.1 \%$ among several smallholder farmers. Umoren (2008) also recorded a default rate of $55.53 \%$ among Agricultural Credit Guarantee Scheme (ACGS) loan beneficiaries in Akwa Ibom State. In Anambra State, $70 \%$ of smallholder farmers who benefited from loans granted by the state government are yet to respond positively to repayment (Obi, 2008). A study conducted by Afolabi (2002) on analysis of loan repayment among small scale farmers in Oyo state, Nigeria revealed that $66.99 \%$ of the sampled small-scale farmers used their loans farm operations such as payment for hired labour, purchase of implements, fertilizers, seeds and other farm inputs, while $31.07 \%$ of them utilized their loans for household purpose which include paying for children education and medical treatment. Only $1.94 \%$ of them spent their loan proceeds on meeting the expenses of feeding and clothing the family. In Akwa lbom State, loan repayment from the beneficiaries/participants of the Integrated Farmers' Scheme (IFS) has been the major problem faced by the scheme. Loan disbursed to the participants has mostly not been repaid when due. This condition tends to create some problems to the staff and management of the scheme as well as the State government granting the credit since the loans were supposed to be revolving. The farmers feel that it is government money 
which they should have a share of and as such refuse to make repayment of it (Abasiodiong, 2008). Whatever the reasons for default, there is greater need to reduce or provide solutions to default/ non repayment of agricultural credit under the Akwa Ibom State Integrated Farmer's Scheme (IFS) so that greater funds can flow into agriculture. This could be achieved through empirical studies of the scheme. This is the focus this research. It is against this background that the study examines the loan default and repayment performance of Akwa Ibom State Integrated Farmers' Scheme (IFS). Objectives of the study are to (i) estimate the rate of loan defaults among Akwa Ibom State Integrated Farmers' Scheme (IFS) participants in Akwa Ibom State (ii) determine the factors that influence loan default by beneficiaries.

\section{THEORETICAL FRAMEWORK}

Loan Default model. Lenders grant productive credit to his customer under the condition of imperfection (Udoh, 2008). The lender cannot ascertain that the customer will repay the loan under the acceptable contract terms. Thus loan repayment by the customer is a probability decision such as full loan repayment, partial loan repayment and no loan repayment as when due. This probability of full loan is represented as:

$$
\operatorname{PrF}\left(\mathrm{L}_{\mathrm{i}}\right)=\mathrm{E}\left(\mathrm{L}_{\mathrm{i}}+\theta_{1}\right)
$$

where:

$\mathrm{L}_{\mathrm{i}}=$ The amount of loan repaid at specified interest rate: $\mathrm{i}$

$\theta_{1}=$ The amount of interest the customer pays to the lender for using the loan within the specified time period

Equation (1) depicts that an equilibrium state of financial contract between lender and the borrower is attained where the probability of default is zero. In a situation of partial and no repayment, the equilibrium is distorted bringing the probability of default as shown below:

$$
\operatorname{PrD}\left(L_{i}\right)=E\left(L_{i}+\theta_{1}\right)-\eta_{r t}
$$

where: $\eta_{r t}=$ Composite default effect of partial $(p)$ and no $(n)$ repayment at specifictime period. Thus $r=p+n$.

The incorporation of $\eta_{\mathrm{rt}}$ in equation (2) is meant to show the crowding out effect of failure of borrower to meet contractual arrangement, which is considered as an exogenous cost to the lender. The magnitude of $\eta_{r t}$ indicates the intensity of borrower deviation from the financial contract and it approaches 1 when the borrower has not made any repayment. i.e $\eta_{\mathrm{rt}} \rightarrow 1$ for no repayment

Taking $\eta_{\mathrm{rt}}$ as an event that occur when loan is granted to a borrower, then it is right to say that $\eta_{\mathrm{rt}}$ will happen, say e to 1 odd. This means that it is possible that $\eta_{\mathrm{rt}}$ will occur e times as likely that $\eta_{\mathrm{rt}}$ will occur. Statistically, e to f odds will be taken to mean the same thing as $\mathrm{e} / \mathrm{f}$ to 1 i.e, the ratio between the two numbers is the only quantity of importance, when stating odd $f$. If it is times as likely that $\eta_{r t}$ will not occur, then the probability that $\eta_{r t}$ occurs must be $\mathrm{e} /(\mathrm{e}+1)$ since we have:

$$
\begin{aligned}
& P\left(\eta_{r t}\right)=e P\left(\eta_{r t}\right) \\
& P\left(\eta_{r t}\right)+P\left(\eta_{r t}\right)=1
\end{aligned}
$$

Generally, the statement that the odds are e to $f$ in favour of event $\eta_{\mathrm{rt}}$ occurring is equivalent to the statement that

$$
\underset{e}{e}\left(n_{\mathrm{ft}}\right)=\underline{e}
$$



obtain:

If we let $P\left(\eta_{r t}\right)=P$, then the equation (5) can easily be solved for e/f in terms of $P$; we

$$
\mathrm{e} / \mathrm{f}=\mathrm{p} /(1-\mathrm{p})
$$

\section{METHODOLOGY}

The study area. The study was conducted in Akwa Ibom State, Nigeria. It is one of the 36 States in the Nigeria with 31 local government areas and it is a major crude oil producing State in the Niger Delta region. The population is about 3.92 million people (NPC, 2006) and over $70 \%$ are involved in agriculture for both subsistence and income generation. The State falls within the humid tropics with two distinctive seasons- dry and rainy season. Mean daily maximum temperature are regular about $260-330 \mathrm{C}$ and the relative humidity is between 50 to $60 \%$ during the dry season and between 60 and $90 \%$ in the rainy season. The favorable climate encourages extensive agricultural production.

Population of the study. The targeted population for the study was the participants of the Akwa Ibom State Integrated Farmers' Scheme (IFS) from 2000 - 2008.

Sample size and data collection. The data used in the study were both primary and secondary in nature. The secondary data were obtained from the official records of the Akwa Ibom State Integrated Farmer's Scheme (IFS) where two batches of the loan beneficiaries were selected. The first batch consists of the 153 beneficiaries while the second batch consists of 184 beneficiaries, resulting to a total number of 337 beneficiaries. The primary data were obtained through the use of a set of well structured questionnaire which was administered to selected IFS loan beneficiaries. Simple random sampling technique was used to select 30 and 70 IFS loan beneficiaries from the first and second batches respectively using the list of IFS loan beneficiaries, which was obtained from the accounts Department of the Akwa Ibom State Integrated Farmers' Scheme, Uyo. This gives a total of 100 loan beneficiaries for the study.

Data analysis. Loan Repayment Index (LRI) and Loan Default Index (LDI) were to estimate the rate of loan default among IFS participants in the study area. Tobit model was used to estimate the factors influencing loan default by beneficiaries in the study area.

Loan Performance Measures. These involved the evaluation of an index: Loan repayment index.

Loan repayment index:

$$
L R I=\left[B V R_{t} / V B+w_{2}\left(B V R_{P /} V B\right)\right]^{*} 100(\text { Udoh, 2008) }
$$

where:

$\mathrm{LRI}=\mathrm{Loan}$ repayment index shows the level of loan repayment made by a loan beneficiary.

$\mathrm{W}_{2}=\mathrm{NRC}_{\mathrm{P}} / \mathrm{TNLO}_{\mathrm{P}}$

$\mathrm{BVR}_{\mathrm{f}}=$ Value of loan collected by those who made full repayment

$\mathrm{VB}=$ Total value of loan outstanding.

$B V R_{P}=$ Value of loan collected by those who made partial repayment.

$N R C_{P}=$ Number of borrowers who made partial repayment.

$\mathrm{TNLO}_{\mathrm{P}}=$ Total number of borrowers who have outstanding loan to repay.

Loan default index:

$$
\mathrm{LDI}=100-\mathrm{LRI}
$$

Borrower Repayment Rate. This is given as:

$$
\mathrm{BRR}=\left[\mathrm{BNF}_{\mathrm{f}} / \mathrm{NB}+\mathrm{w}_{2}\left(\mathrm{BNR} \mathrm{R}_{\mathrm{p}} / \mathrm{NB}\right)\right]^{\star} 100
$$

where: BRR is the borrowers' repayment rate, which is defined as the rate at which the borrowers repay or fulfill their loan obligation; 
$\mathrm{w}_{2}=\mathrm{VRCp} / \mathrm{TVLOp} ;$

$\mathrm{BNFf}=$ number of borrowers who made full repayment;

$\mathrm{NB}=$ total numbers of beneficiaries in a particular period;

$\mathrm{BNRp}=$ numbers of borrowers who made partial repayment;

$\mathrm{VRC} p=$ value of repayment collected from those who made partial repayment; TVLOp = total value of loans outstanding for those who made partial repayment.

Borrowers' default index is then measures as follows:

$$
\mathrm{BDR}=100-\mathrm{BRR}
$$

where BDR is borrowers' default ratio.

Loan default determinants. In finance, a default occurs when a debtor fails to make the required payment on a timely basis or to comply with other conditions of an obligation or agreement. Default may occur if the debtor is either unwilling or unable to pay their debt. This can exist in agricultural loans in Nigeria. The inability of IFS loan beneficiaries to meet contractual obligation as agreed as when due results to default by them. However, there are degrees and intensities of defaulting. This perspective indicates that Tobit estimation should be adopted (Tobin, 1958). The study adopts this Tobit model with the assumption that the concentration of the dependent variable $X_{t}$ cluster towards the left limit (i.e zero) and because it does not only explain the value of the dependent or the probability of defaulting or not defaulting but also the magnitude of the default.

Udoh (2008) in a study to estimate the loan default among beneficiaries of a state government owned Agricultural loan scheme developed a loan default model as specified by McDonald and Moffat (1980). This same model was also adopted by Umoren (2008) in the analysis of loan defaults among Agricultural Credit Guarantee Scheme (ACGS) farmers in Akwa Ibom State. This study is also adopting this model developed by Udoh (2008) as follows:

\section{Let IA ${ }^{*}=$ Intensity of loan default}

$\mathrm{IA}^{*}=$ The solution to utility maximization problem of intensity of loan default subject to a set of constraints per IFS loan beneficiary in Akwa Ibom State and conditional on being above a certain limit.

$$
\begin{aligned}
& I A_{0}=\text { Situation of full repayment } \\
& \text { Therefore } I A=I A^{*} \text { if } I A^{*}>I A_{0} \\
& =0 \text { if } I A^{*} \leq I A_{0}
\end{aligned}
$$

The above equation represents a censored distribution of intensity of defaulting because the value of IA for full loan repayment equal zero.

Following Tobin (1958), the expected intensity of IFS loan default E (IA) is expressed as:

$$
E(I A)=X \beta F(z)+\delta f(z)
$$

where:

$\mathrm{X}=\mathrm{a}$ vector of explanatory variable

$F(z)=$ the cumulative normal distribution of $z$

$f(z)=$ the value of the derivative of the normal curve at a particular point

$z=$ the $z$-score for the area under the normal curve

The Tobit Model. The Tobit model is an econometric, biometric model proposed by James Tobin (1958) to describe the relationship between a non-negative dependent variable $Y_{t}$ and an independent variable (or vector) $x_{i}$

$$
\text { Tobit model }=\beta_{0}+\beta_{1} x_{i}+\mu_{i}
$$


$Y_{i}^{*}=a$ latent variable representing borrower's i's propensity to default

$\beta_{0}=$ the Intercept (constant) term

$\beta_{1}=$ Vector of parameters to be estimated

$\mu_{i}=a$ homoscedastic, normally distributed error term

$\mathrm{x}_{\mathrm{i}}=\mathrm{A}$ vector of independent variables as defined below.

These variables specified are those factors that affect IFS loan default as identified from various literatures.

\section{RESULTS AND DISCUSSION}

The rate of loan default among Integrated Farmers' Scheme (IFS). The result of the rate of default among integrated farmers' scheme is shown in Table 1. The result reveals that out of 337 participants which consist of 153 and 184 beneficiaries from both the first and second batch which benefited from the loan, only one beneficiary $(0.3 \%)$ made full repayment while $92(27 \%)$ and $242(72 \%)$ made partial and no repayment respectively. In both batches, over $90 \%$ of the beneficiaries defaulted. There was no full repayment in the first batch while about $0.6 \%$ of the total loan disbursed was fully repaid in the second batch. Also, about $7.9 \%$ and $6.1 \%$ of the amount were partially repaid in the first and second batch respectively. Of this amount, $7.4 \%$ and $10.3 \%$ were partially repaid by males and females respectively in the first batch while about $6.0 \%$ and $4.6 \%$ were partially repaid by males respectively in the second batch.

On the contrary, about $92.1 \%$ and $93.9 \%$ of the loan were held by beneficiaries who did not make any form of repayment in the first and second batch respectively. About 92.6 and $89.6 \%$ of the amount were held by males and females respectively in the first batch while about $93.9 \%$ and $95.4 \%$ of the amount were held by males and females respectively in the second batch. The result also shows about $93.4 \%$ and $92.9 \%$ of the amount was held by males and females respectively in both batches.

Table 1 - Loan Statistics of AKSIFS (2000 - 2058)

\begin{tabular}{|c|c|c|c|c|c|c|c|}
\hline \multirow{2}{*}{ Description } & \multicolumn{5}{|c|}{ 1st Batch } & \multicolumn{3}{c|}{ 2nd Batch } & \multirow{2}{*}{ Grand Total } \\
\cline { 2 - 8 } & Male & Female & Total & Male & Female & Total & 337 \\
\hline Beneficiaries & 126 & 27 & 153 & 153 & 32 & 184 & $108,442,955$ \\
\hline $\begin{array}{c}\text { Amount granted } \\
\text { as loan (N) }\end{array}$ & $33,498,668$ & $6,686,657$ & $40,658,776$ & $59,658,854$ & $8,598,854$ & $68,257,630$ & 1 \\
\hline $\begin{array}{c}\text { No. of } \\
\text { beneficiaries } \\
\text { who fully paid }\end{array}$ & - & - & - & 1 & - & & 1 \\
\hline $\begin{array}{c}\text { Amount fully } \\
\text { paid (N) }\end{array}$ & - & - & - & 299,800 & - & 299,800 & 299,800 \\
\hline $\begin{array}{c}\text { No. of } \\
\text { beneficiaries } \\
\text { who partially } \\
\text { paid }\end{array}$ & 52 & 8 & 60 & 27 & 5 & 32 & 92 \\
\hline $\begin{array}{c}\text { Amount partially } \\
\text { repaid (N) }\end{array}$ & $2,488,150$ & 690,000 & $3,178,150$ & $3,590,500$ & 391,500 & 3982,000 & $7,160,150$ \\
\hline $\begin{array}{c}\text { No. of } \\
\text { beneficiaries } \\
\text { who made no } \\
\text { repayment }\end{array}$ & 83 & 9 & 92 & 125 & 25 & 150 & 242 \\
\hline $\begin{array}{c}\text { Amount not } \\
\text { repaid (N) }\end{array}$ & $31,010,518$ & $5,996,659$ & $37,007,175$ & $56,068,276$ & $8,207,354$ & $64,275,630$ & $101,282,805$ \\
\hline $\begin{array}{c}\text { Amount repaid } \\
\text { (N) }\end{array}$ & $2,488,150$ & 690,000 & $3,178,150$ & $3,890,300$ & 391,500 & $4,281,800$ & $7,459,950$ \\
\hline
\end{tabular}

Source: Akwa Ibom State Integrated Farmers' Scheme (AKSIFS). 
Loan default and performance measures. The result reveals that over $90 \%$ of the loan disbursed by Integrated Farmers' Scheme (IFS) in the period under review was still being held by the participants. This shows a very high level of default by the participants. In order to fully evaluate the rate of loan default, loan performance indices are estimated and presented on Table 2. The various measures of default and performance computed and shown on Table 2 indicate high rates of loan default among the participants in the first and second batch of the Integrated Farmers' Scheme. About $99.96 \%$ of the loan granted to borrowers during the period under review were not repaid when due. This amount is however held by about $99.91 \%$ of the loan beneficiaries. This result of high loan default is in consonance with the finding of Umoren (2008) and Udoh (2008). This high level of default and large loan losses could lead to the collapse of the Scheme or loss of interest.

Table 2 - Loan default and performance

\begin{tabular}{|l|l|l|l|l|l|}
\hline \multirow{2}{*}{ Loan performance indices } & \multicolumn{2}{c|}{ 1st Batch } & \multicolumn{2}{c|}{ 2nd Batch } & \multirow{2}{*}{ Average \% } \\
\cline { 2 - 6 } & Male \% & Female \% & Male \% & Female \% & \\
\hline LRI & 0 & 0 & 15.70 & 0 & 15.70 \\
\hline BRR & 8.30 & 12.59 & 9.08 & 7.98 & 9.49 \\
\hline LDI & 100 & 100 & 99.84 & 100 & 99.96 \\
\hline BDR & 99.92 & 99.87 & 99.91 & 99.92 & 99.91 \\
\hline
\end{tabular}

Source: Computed from equations 7, 8, 9 and 10

$L R I=L o a n$ repayment index

$B R R=$ Borrower's repayment rate

$L D I=L o a n$ default index

$B D R=$ Borrower's default rate

Estimation of factors that affect IFS default among the beneficiaries in Akwa lbom State, Nigeria. The result of the Tobit model is indicated in Table 3. The Tobit model was employed to determine factors influencing loan default by beneficiaries. The model seeks to explain the probability of loan default as a result of any the 16 identified independent variables. The signs and significance of the coefficient of the independent variables will be used in determining largely the impact of each variable on probability of loan default among beneficiaries. The model has a good fit and it is significant at 5\%. The log likelihood of loan default was -48.25 . The result shows that eight (8) explanatory variables were significant at $5 \%$ while the remaining eight (8) explanatory variables were significant.

The significant variables include material status, household size, additional source of income, total farm cost, enterprise probability, debt-asset ratio, ratio of amount requested/given and number of visits by supervisors. The marital status of the beneficiaries has a negative coefficient and it is statistically significant $5 \%$. This indicates that there is an inverse relationship between marital status and loan default. This showed that married beneficiaries were more prone to default in loan repayment than singles. This might be associated with high domestic expenditures in maintaining the family. Given the limited income beneficiaries in the study area increased family budgets would imply greater probability of default in loan repayment. The household size of the beneficiaries has a positive coefficient and it is statistically significant at $5 \%$. This reveals that there is a direct relationship between household size and loan default. This implies that those beneficiaries with larger household size tend to default more than those whose household size is smaller. This could be due to the responsibility of gathering for the household needs, including both children and adult dependence. This finding supports that of Udoh (2008).

Off-farm income by the beneficiaries has a negative coefficient and is statistically significant at $5 \%$. This indicates that there is an inverse relationship between having an additional source of income and loan default. This shows that those beneficiaries without offfarm income tend to default more than those having off-farm income. This is due to the fact that their daily needs are funded from the proceeds of the micro-business and this hinders savings, capital accumulation and asset formation for expansion. The total farm cost has a positive coefficient. This shows that there is a direct relationship between total farm cost and loan default, suggesting increase in loan default as the total farm cost increases. This is so 
because beneficiaries who encounter high cost of production would likely not make enough profit sufficient to meet the financial commitment attached to loan collected. Enterprise profitability has a negative coefficient and is statistically significant at $5 \%$. This indicates an inverse relationship between enterprise profitability and loan default. The estimation shows that the probability of default on loan repayment would decrease as enterprise profitability increases. This supports the findings of Lugemwa and Darrach (1996).

The farmer's debt-asset ratio has a positive coefficient and significant at $5 \%$. This shows a direct relationship between debt-asset ratio of beneficiaries and loan default. An increase in the beneficiaries' debt-asset ratio will increase his probability of defaulting in loan repayment. A high level of indebtedness might contribute to the low levels of repayment. This is in consonance with the findings of Topho et el., (1995) that debt to asset ratio is an important factor for determining loan success or failure. Ratio of amount requested/given has a positive coefficient, suggesting that there is increase in loan repayment as the amount or size loan given increases. This is possible due to the advantages associated with the economics of scale, which comes about through the expansion of purchases and production (Okorji and Mejeha, 1993). The number of visits by supervisors has a negative coefficient and is significant at $5 \%$. This indicates an inverse relationship shows that the probability of default in loan repayment would decrease as the number of visits by supervisor's increases. This is so because project monitoring and evaluation is effective in loan repayment.

Table 3 - Estimation of the factors that affect IFS default among the beneficiaries

\begin{tabular}{|l|l|l|}
\hline \multicolumn{1}{|c|}{ Explanatory variables } & \multicolumn{1}{c|}{ Coefficient } & \multicolumn{1}{c|}{$\mathrm{t}$-value } \\
\hline Constant & 3.7461 & 0.18 \\
\hline Batch & -0.2045 & -1.61 \\
\hline Age & -0.0115 & -0.56 \\
\hline Gender & -0.1985 & -1.56 \\
\hline Marital Status & $-0.1209^{* * *}$ & -19.15 \\
\hline Household size & $0.0152^{*}$ & 1.78 \\
\hline Off-farm income & $-0.1446^{* * *}$ & -14.39 \\
\hline Size of income & $-1.33 \mathrm{e}-06$ & -0.38 \\
\hline Education level & 0.0154 & 0.37 \\
\hline No, of years out of formal education & 0.0092 & 0.00 \\
\hline Total farm cost & $0.3925^{\star * *}$ & 3.27 \\
\hline Amount of loan obtained & -3.9532 & -0.10 \\
\hline Enterprise profitability & $-0.8511^{* * *}$ & -4.43 \\
\hline Debt-asset ratio & $0.3238^{* * *}$ & -4.43 \\
\hline Ratio of amount requested/given & $0.7859^{\star * *}$ & 3.19 \\
\hline Agro-enterprise diversification & 0.2055 & 0.91 \\
\hline No. of visits by supervisors & $-0.0235^{* * *}$ & -16.85 \\
\hline sigma & 0.4044 & 0.29 \\
\hline Number of Observations & 99 & \\
\hline LR Chi ${ }^{2}(16)$ & 13.27 & \\
\hline Prob > Chi ${ }^{2}$ & 0.85 & \\
\hline Log Likelihood & -48.26 & \\
\hline Psud $\mathrm{R}^{2}$ & 0.52 & \\
\hline
\end{tabular}

${ }^{* * *}$ Significant at $1 \%$

\section{CONCLUSION}

Loan default and performance measures estimated indicate low level of repayment among beneficiaries during the period under review. Accordingly, the indices revealed that over $90 \%$ of the loans disbursed by the Akwa Ibom State Integrated Farmers' Scheme (IFS) to the first and second batches of the beneficiaries were still held by the participants. This situation is a high level of loan default among the benefiting farmers. In order to improve the Integrated Farmers' Schemes overall performance and cut down loan default rates among participants, the following recommendations are tenable: 
1. Adequate fund should be granted to the participants on request at the appropriate time to avoid the diversion of such loans and in view of the time bound nature of agricultural operations.

2. Government should organize regular training programmes for IFS Supervisors to enhance effective supervision and appraisal of the agricultural projects. This will check the incessant waste of fund that disrupts prompt repayment of such loans.

3. More vehicles should be provided by Government to enhance effective monitoring of the progress of participants' projects, assist when necessary and offer advice.

4. Extension officers should also be trained and adequately mobilized to provide wellorganized and effective extension services in relation to production efficiency.

\section{REFERENCES}

1. Abasiodiong, M. U. (2008) Beyond the limits of microcredit: strategic options for women socio-economic empowerment and poverty reduction. A paper presented at the 3rd Business Women Forum: Doha, State of Qatar, January, 2008.

2. Afolabi, J. A. (2002) Economic analysis of loan repayment among small scale farmers in Oyo State. Unpublished Ph.D. Thesis, Department of Agricultural Economics and Extension, Federal University of Technology, Akure.

3. Ajekigbe, J. (2006) Financial Intermediation for unlocking agricultural potential in Nigeria. In: Agriculture and agribusiness: achieving the target growth. A paper presented at the 5th in Nigerian Economic Summit Group (NESG), agriculture Summit Abuja, F.C.T, Nigeria. 2 (1), 52-62.

4. Akubuilo, C. J. (2002) Poverty alleviation in agriculture: Study of rural women farmers in Enugu agricultural zone of Enugu State, Nigeria. Journal of Science of Agriculture, Food of Technology and Environment, 6 (4), 50-55.

5. Nnadozie, A. K., Uzoigwe, J. I. (2002) Effectiveness of loan sanctions on agricultural loan repayment under community banking in Enugu State, Nigeria. Journal of the Science of Agriculture, Food of Technology and Environment, 2 (1), 52-62.

6. Derosa, D. A. (1995). Regional trading arrangement among developing countries, The Asia example. IFPRI Research Report IFRI 103, Washington D. C, USA. pp. 1-4.

7. Duong, P. B., Izumida, Y. (2002) Rural development finance in Vietnam, a microeconometric analysis of household surveys. World Development, 30 (2), 319-335.

8. Edache, E. A. (2006) New strategies for achieving a 10 percent growth rate in Nigeria agriculture. A paper presented at the 5th Nigerian Economic Summit Group (NEST) Agriculture Summit Abuja, FCT, Nigeria, November, 2006.

9. Emecheta, H. M. (1998) Agricultural credit administration by River basin and rural development authority: A case study of Imo River Basin and Rural Development Authority. In: Readings in Agricultural Finance ( ljere, M.O. and Okorie, A., eds), Lagos: Longman, pp. 66-74.

10. Ojo, M. O. (1998) Some implications of government under economic policies for financing and development of agriculture in Nigeria. In: Readings in agricultural finance (ljere, M.O. and Okorie, A., eds), Lagos: Longman, pp. 16-24.

11. Ijere, M. O (1986) New perspective in financing Nigerian Agriculture. Enugu: Fouth Dimension Publishing Company, pp. 7-37

12. Inyang - Akpan, T. E. (2005) Bank Recapitalization and agricultural Financing in Nigeria. In: Financial reforms and agricultural development in Nigeria. Department of Agricultural Economics and Extension, University of Uyo, Public Lecture Series (1), pp. 16-28.

13. Ladipo, O. O. (1986) Rural Development in Nigeria. Journal of the Federal Department of Rural Development, 2 (2), 62-68

14. Lipsey, R. G. (1981) The understanding and control of inflation, Is there a crisis in macro economics? Canadian Journal of Economics, XIV (4), 545-76.

15. Lugemwa, W., Darrach, M. (1996) Disciminant analysis of seasonal agricultural loan repayment by small-scale farmers in Transkei: Agrekon, 34 (4), 231-234. 
16. McDonald, J. F., Moffat, R. A. (1980) The use of Tobit Analysis. Review of Econometrics and Statistics. Vol. 62, pp.318-320.

17. Obi, A. A. (1980) Methods, cost efficiency and improvement of agricultural credit supervision. Department of Agricultural Economics, University of Nigeria, Nsukka.

18. Okam, C. O. (1994) An evaluation of agricultural of loan disbursement and repayment patterns of Nigeria Agricultural and Cooperative Bank (NACB): A case study Cross River State. Department of Agricultural Economics and Extension, University of Calabar, Nigeria

19. Okorie, A. (1988) The role of commercial bank in funding agriculture in Nigeria (19601984). Savings and Development, 11, 311-314.

20. Okorji, E. C., Mejeha, R. O (1993) The forma agricultural loans in Nigeria: the demand for loans and delinquency problems of smallholder farmers in Owerri agricultural zone of Imo State. Nigeria Int. J. Tropical Agriculture, 1: 1-13.

21. Osuntogun, A. (1983) Agricultural credit strategies for Nigerian farmers. USAID spring review of small holder's credit, volume 6, February.

22. Oyewole, B. A., Oloko, S. A. (2002) Agricultural and food losses in Nigeria - the way out. Department of Agricultural Engineering, The Federal Polytechnic, Ado-Ekiti, Nigeria

23. Tobin, J. (1958) Estimation of relationships for limited dependent variables. Econometrica, 26, 24-36

24. Topho, E. R., Held, L. J., Schroeder, A. (1995) Predicting successful versus unsuccessful borrowers with financial ratio. J. Am. Soc. Farm Managers and Rural Appraisal, 1, 166173.

25. Udoh, E. J. (2008) Estimation of loan default among beneficiaries of State Government owned Government agricultural loan scheme in Nigeria. Journal of Central European Agriculture, 9 (2), 343-352.

26. Umoren, A. A. (2008), Analysis of Agricultural Credit Guarantee Scheme (ACGS) loan default among beneficiaries in Akwa lbom State, Nigeria. Unpublished M.Sc Thesis, Department of Agricultural Economics and Extension, University of Uyo, Nigeria.

27. Yoichiro, H., Hari, S. (1996). A continuum of informality of credit of credit: What can informal lenders teach us? Savings and Development Quarterly Review, 2, 207-221. 